\title{
Dynamic Beheviour of qZS-based Bi-directional DC/DC Converter in Supercapacitor Charging Mode
}

\author{
Janis Zakis ", Dmitri Vinnikov ${ }^{*}$, Oleksandr Husev ${ }^{*}$, Ivars Rankis ${ }^{* *}$ \\ ${ }^{*}$ Tallinn University of Technology (Estonia) \\ ${ }^{* *}$ Riga Technical University (Latvia) \\ janis.zakis@,ieee.org
}

\begin{abstract}
This paper presents a bi-directional quasi-Zsource inverter (qZSI) based DC/DC converter for supercapacitor (SC) interfacing in high power applications. In the SC charging mode the proposed converter acts as a conventional VSI based step-down converter, but in the energy recovery mode it acts as a qZSI-based step-up DC/DC converter. The paper analyzes and discusses the operation of the converter in the SC charging mode. The analysis of the static model of the converter as well as the Bode diagram are presented. Theoretical results are verified by experimental results on a $500 \mathrm{~W}$ prototype converter.
\end{abstract}

Keywords- Bidirectional power flow, DC/DC power converters, energy conversion, energy storage

\section{INTRODUCTION}

Distributed power generation systems powered by fuel cells (FC), photovoltaic cells (PV) or wind generators together with a supercapacitor (SC) are common in residential applications, in the automotive industry as well as in geographically complex places.

It is well known that systems without a SC are unable to react on sudden high power demand spikes. For that reason the SC usually is the key element that can provide system flexibility and can obey temporary high power demands. Fig. 1 shows the general block diagram of a distributed power generating system with a SC.

This paper discusses the interface converter which provides bi-directional power flow between the $\mathrm{SC}$ and the main system or supported system (SS) Fig. 1. The proposed interface converter in Fig. 2 consists of a voltage-fed qZS-network $\left(D, L_{1}, L_{2}, C_{1}, C_{2}\right)$ which is coupled with VSI $\left(T_{1} \ldots T_{4}\right)$ [1-3] in the SC side, a medium frequency isolation transformer $(T R)$ and a VSI $\left(T_{5}, T_{6}\right)$ in the SS side.

In general, the operation modes of the proposed bidirectional converter can be subdivided as the charging mode and the discharging mode of the SC [4-6].

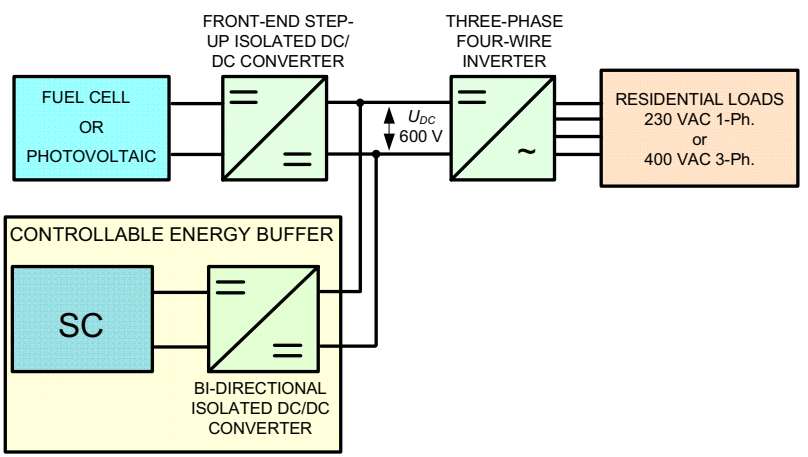

Fig. 1. General block diagram of the distributed power generation system with a SC-based controllable energy buffer.

During the charging of the SC, the converter operates in the voltage buck mode and the charging process of the SC is controlled by the SS side half-bridge VSI. In the energy recovery mode, the supported energy system is being supplied from the SC. To ensure the constant DClink voltage $\left(U_{D C}\right)$ level in the conditions of the discharging of the SC, the qZSI with the shoot-through PWM control is used to boost the decreasing voltage of the SC [4-6].

The aim of this paper is to present an additional analysis of the converter during the SC charging mode. The impact of the qZS-network on the SC charging process will be discussed in detail.

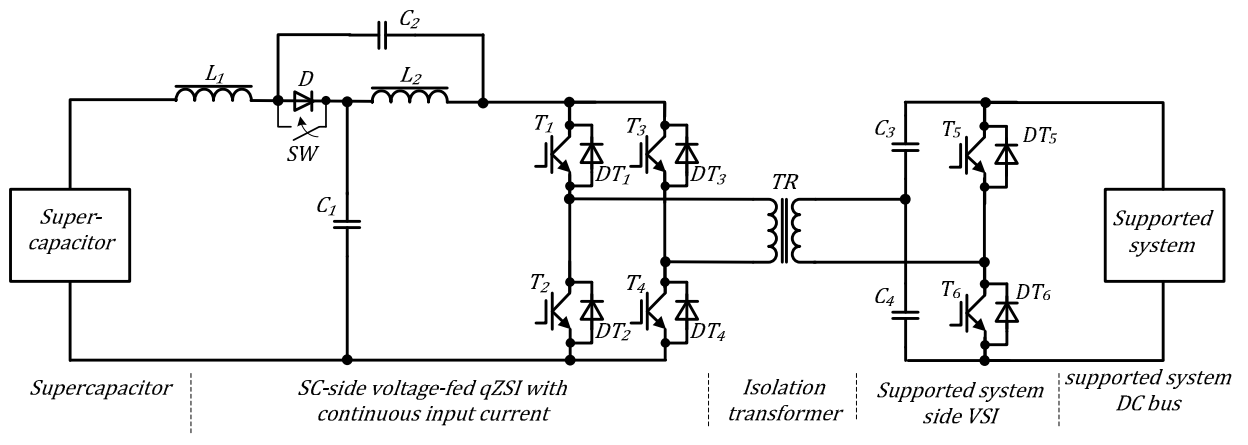

Fig. 2. General power circuit of the proposed bi-directional DC/DC converter for SC interfacing. 


\section{OpERATION IN THE SC CHARGING MODE}

The discussed converter performs in the charging mode if $U_{S S}$ is in its rated value. If it is the case, then the SC is being charged up to a nominal voltage $\left(U_{S C}\right)$. In this regime the converter operates in the voltage step down mode performing power transfer from the SS DC-bus to the SC. Fig. 3 presents the general power circuit configuration in the SC charging mode.

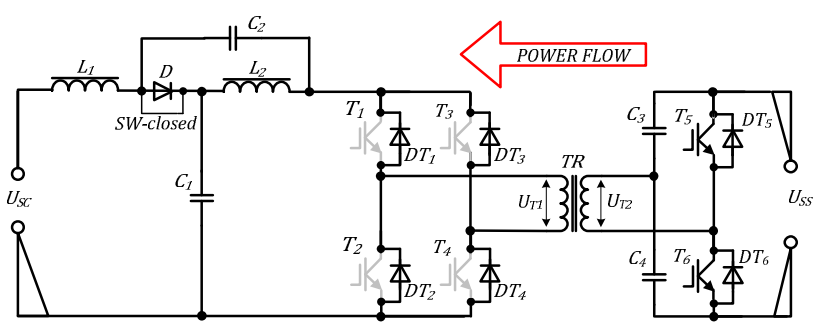

Fig. 3. General power circuit of the proposed converter in the SC charging mode.

In this operation mode, SC side VSI transistors are not conducting, but antiparallel diodes $\left(D T_{1} \ldots D T_{4}\right)$ operate as a full-bridge rectifier. Since the diode $D$ of the qZSnetwork is reverse biased during the charging mode, it should be shunted with switch $S$. Passive elements $\left(L_{1}, L_{2}\right.$ and $C_{1}, C_{2}$ ) of the qZS-network perform as a low-pass filter.

The charging process of the $S C$ is controlled by adjusting duty cycle $D$ of SS side transistors $T_{5}$ and $T_{6}$ in the half-cycle of transformer's voltage.

Neglecting losses in the circuit elements, the voltage transformed in the primary winding when one of the both switches $\left(T_{5}\right.$ or $\left.T_{6}\right)$ conducts can be expressed as

$$
L_{T r} \frac{d i}{d t}=0.5 n U_{S S}-U_{S C},
$$

where $L_{T r}$ is leakage inductance of transformer reduced to the primary side, $U_{S S}$ is the voltage of the supported system DC bus, and $n$ is the turns ratio of the isolation transformer:

$$
n=\frac{w_{1}}{w_{2}}=\frac{U_{T 1}}{U_{T 2}},
$$

Where $w_{1}$ and $w_{2}$ are number of turns in windings, $U_{T 1}$ and $U_{T 2}$ are amplitude voltages of the primary (SC side) and the secondary side (SS side) windings of the isolation transformer, respectively.

When the switch is turned-off then energy stored in magnetic system provides passing of current in the primary winding through anti-parallel diode of the other switch and polarity of voltage across winding is changed

$$
L_{T r} \frac{d i}{d t}=-0.5 n U_{s s}-U_{s c} .
$$

As a result the current at the rectifier output is decreasing.

In the first part transformer current rises-up to amplitude value of

$$
I_{m}=\frac{D\left(0.5 n U_{S S}-U_{S C}\right)}{L_{T r} f_{0}},
$$

but in the second part - decreases to zero value in time duration

$$
t_{d}=\frac{D\left(0.5 n U_{S S}-U_{S C}\right)}{f\left(0.5 n U_{S S}+U_{S C}\right)} .
$$

When $t_{d}<(1-D) T$ then current shape is discontinuous. The mean value of supercapacitor charging current is

$$
I_{S C}=0.5 I_{m}\left(D+t_{d} f\right) .
$$

At boundary operation case when $t_{d}=(1-D) T$ the mean value is $I_{S C}=0.5 I_{m}$. From (5) it's possible to find the duty cycle for boundary case

$$
D_{b}=0.5+\frac{U_{S C}}{n U_{S S}} .
$$

\section{ANALYSIS OF THE STATIC MODEL}

To analyze the processes in the qZS-network during the operation in the charging mode, Fig. 4 presents the equivalent circuit of the converter. To acquire more precise analysis, the qZS-network $\left(C_{1}, C_{2}, L_{1}, L_{2}\right)$ is discussed together with the leakage inductance of the transformer $L_{T r}$. Fig. 5 shows the theoretical current and voltage waveforms of this scheme.

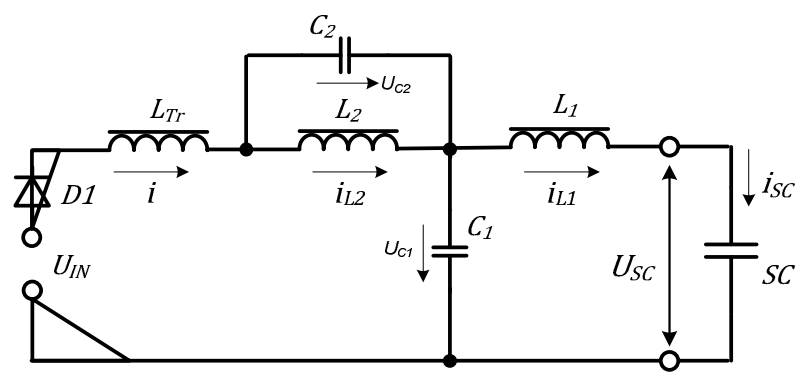

Fig. 4. Equivalent circuit of the converter during the SC charging mode.

The average current of rectifier output circuit is equal to the average value of the current of inductor $L_{l}\left(I S C=I_{L I}\right)$.

The voltage ripple of the capacitors $C_{1}$ and $C_{2}$ can be expressed as

$$
\Delta U_{C 1}=\frac{\Delta I_{L T r} \cdot T}{4 \cdot 2 \cdot C_{1}}
$$

and

$$
\Delta U_{C 2}=\frac{\Delta I_{L T r} \cdot T}{4 \cdot 2 \cdot C_{2}}
$$

respectively.

The current ripple of the inductors $L_{1}$ and $L_{2}$ can be expressed as

$$
\Delta I_{L 1}=\frac{\Delta U_{C 1} \cdot T}{4 \cdot 2 \cdot L_{1}}
$$


and

$$
\Delta I_{L 2}=\frac{\Delta U_{C 2} \cdot T}{4 \cdot 2 \cdot L_{2}}
$$

respectively.

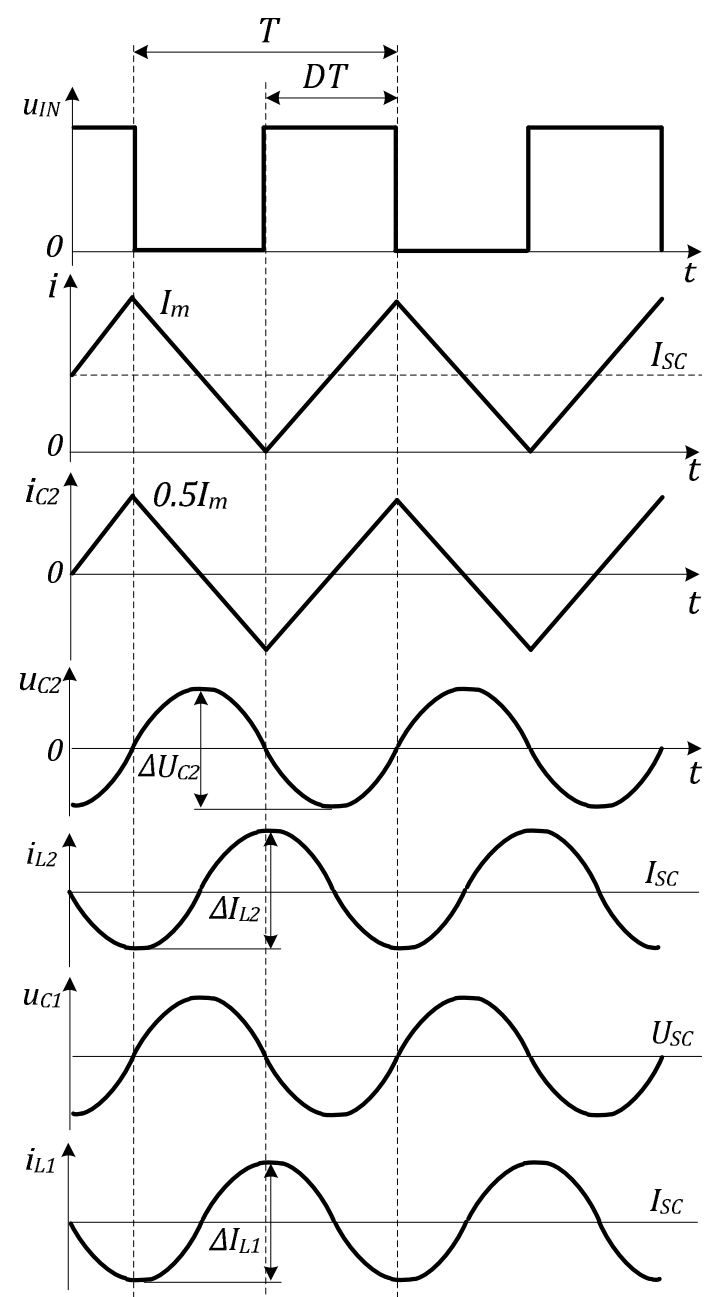

Fig. 5. Operation principle of the qZS-network during the SC charging mode in the boundary case of input current.

As a result, the ripple range of the load current can be calculated as

$$
\Delta I_{L 2}=\frac{n \cdot U_{S S} \cdot\left(0.25-\frac{U_{S C}^{2}}{n^{2} U_{S S}^{2}}\right)}{64 \cdot L_{T r} \cdot L_{2} \cdot C_{1} \cdot f^{3}}
$$

Assuming that the qZS-network is symmetric $\left(L_{1}=L_{2}=L\right.$ and $C_{I}=C_{2}=C$ ), the transformer leakage inductance is $L_{T R}$, capacity of SC is $C_{S C}$ and $\mathrm{SC}$ equivalent series resistance is $R_{E S R}$, the transfer function can be expressed as

$$
\begin{aligned}
& k=\frac{U_{O U T}}{U_{I N}}= \\
& =\frac{\left(R_{E S R}+\frac{1}{j \omega C_{S C}}\right)\left(1-\omega^{2} L C\right)}{\left(1-2 \omega^{2} L C-\omega^{2} L_{\mathrm{TR}} C+\omega^{4} L_{T R} L C^{2}\right)\left(\mathrm{j} \omega L+\left(R_{E S R}+\frac{1}{j \omega C_{S C}}\right)\right)} .
\end{aligned}
$$

Fig. 6 shows the amplitude frequency characteristics (AFC) of the qZS-network that is based on (13) during the charging mode of the SC. Fig. $6 a$ presents the AFC of qZS-network when transformer leakage inductance is 0 . The changes in AFC appear if $L_{T R}$ is $15 \mathrm{mH}$ (Fig. 6b) or more. Fig. $6 b$ shows that the instability of the system occurs at frequencies around $100 \mathrm{~Hz}$. It is recommended to operate the SS side VSI transistors $\left(T_{5}\right.$ and $\left.T_{6}\right)$ at frequencies more than $500 \mathrm{~Hz}$ or to choose another qZSnetwork element values. Also, it is seen from the diagrams that the qZS-network performs as a low-pass filter.

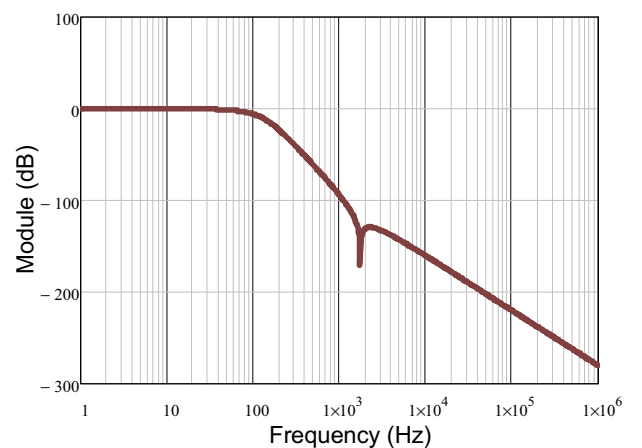

(a)

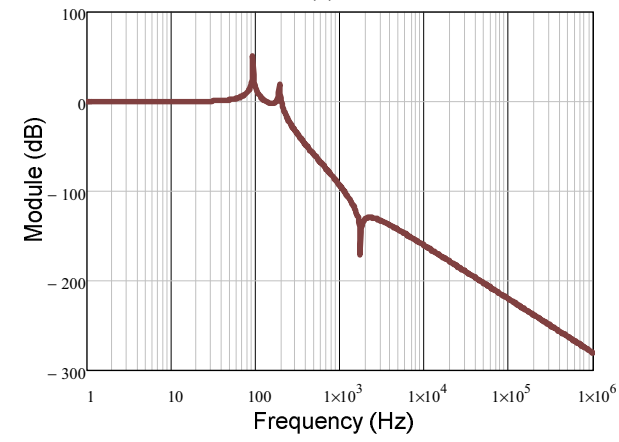

(b)

Fig. 6. AFC of the qZS-network in SC charging mode: $L_{T R}=0 \mathrm{H}$ (a), $L_{T R}=15 \mathrm{mH}$ (b).

\section{SIMULATION AND EXPERIMENTAL RESULTS}

To verify the theory the PSIM model as well as the laboratory prototype were developed according to Fig. 2 . The parameters of the SC stack of two Maxwell Technologies SC modules (PCM14014) connected in series with a total capacitance value of $85 \mathrm{~F}$, rated voltage $28.8 \mathrm{~V}$ and equivalent series resistance $20 \mathrm{~m} \Omega$ were taken as an example for the simulations. General operating and component ratings for the proposed converter are summarized in Table I.

TABLE I GENERAL OPERATION AND COMPONENT RATINGS FOR THE PROPOSED CONVERTER

\begin{tabular}{lc}
\hline \hline \multicolumn{1}{c}{ Parameter } & Value \\
\hline Rated power of converter $P$ & $500 \mathrm{~W}$ \\
Inductance of inductors $L_{l}, L_{2}$ & $60 \mu \mathrm{H}$ \\
Capacitance of capacitors $C_{l}, C_{2}$ & $730 \mu \mathrm{F}$ \\
Capacitance of capacitors $C_{3}, C_{4}$ & $220 \mu \mathrm{F}$ \\
Capacitance of supercapacitor stack $C_{S C}$ & $85 \mathrm{~F}$ \\
Transformer turns ratio, $n$ & $1: 1$ \\
Transformer operation frequency, $f_{T R}$ & $15 \mathrm{kHz}$ \\
\hline Supported system voltage, $U_{S S}$ & $60 \mathrm{~V}$ \\
SC-voltage, $U_{S C}$ & $28.8 \mathrm{~V}$ \\
Duty cycle of VSI switches, $D$ & 0.49 \\
\hline
\end{tabular}


It was assumed that during the charging mode, the SC is charged up to $28.8 \mathrm{~V}$. The supported system side VSI was operated without dead time at the highest possible duty cycle $D=0.49$. A SC is never discharged fully empty. It is considered empty when the terminal voltage of the SC has decreased approximately to half of nominal. That is automatically also initial voltage while charging.

\section{A. Simulation Results}

In simulations the wire active resistances and inductances were taken into account. Fig. 7 shows the charging process of the SC in the interval of $40 \mathrm{~s}$.

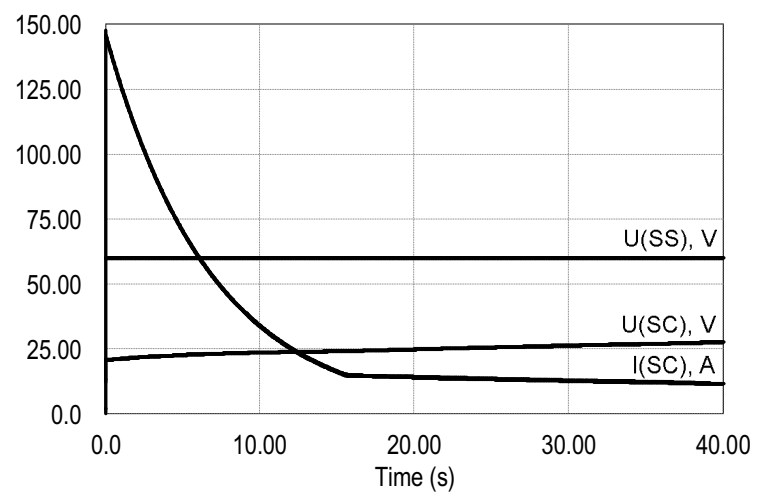

Fig. 7. Operating waveforms of the proposed converter during the SC charging process: SS DC bus voltage $\left(U_{S S}\right)$, SC stack current $\left(I_{S C}\right)$ and SC stack voltage $\left(U_{S C}\right)$.

It can be seen that the SS system DC bus voltage $U_{S S}$ remains the same, but the $\mathrm{SC}$ current $I_{S C}$ decreases proportionally to the SC voltage $U_{S C}$ growth.

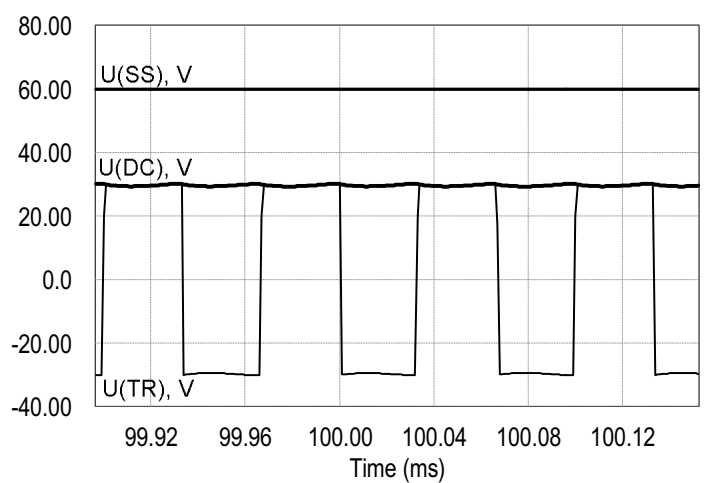

(a)

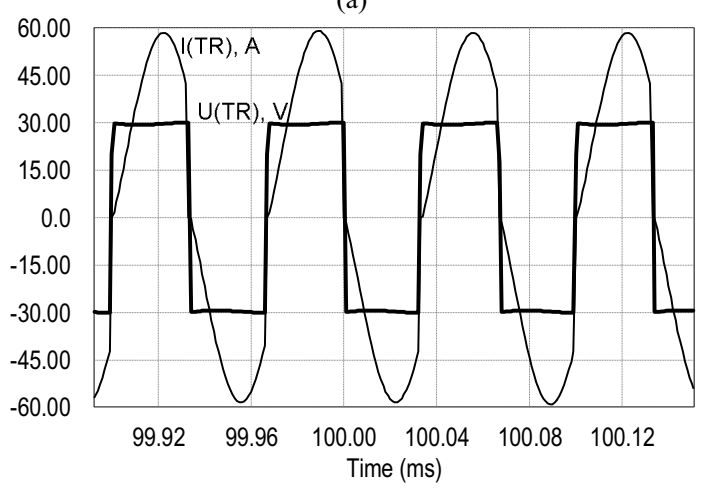

(b)

Fig. 8. Simulation results of the proposed converter during the SC charging mode: SS side voltage $\left(U_{S S}\right)$, transformer voltage $\left(U_{T R}\right)$, DClink voltage $\left(U_{D C}\right)$ (a) transformer voltage $\left(U_{T R}\right)$, and transformer current $\left(I_{T R}\right)(\mathrm{b})$.
Fig. 8 shows the voltage waveforms of the SS system DC bus $U_{S S}$, transformer $U_{T R}$, DC-link voltages $U_{S S}(a)$ and transformer voltage $U_{T R}$ and current $I_{T R}(b)$. Since the half-bridge VSI was used in the SS side, the transformer $U_{T R}$ and the DC-link voltage $U_{D C}$ amplitude $(30 \mathrm{~V})$ is half of the SS DC bus voltage $U_{S S}$ amplitude $(60 \mathrm{~V})$.

Finally, Fig. 9 shows that the $\mathrm{SC}$ is being charged up to the rated voltage $U_{S C}$ if the interface converter SS side voltage $U_{S S}$ is at the predefined value $(60 \mathrm{~V})$.

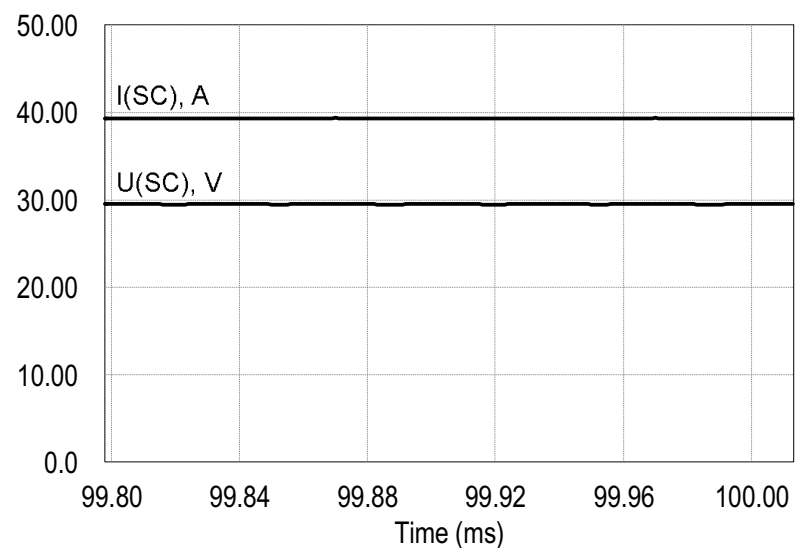

Fig. 9. Simulation results of the proposed converter during the SC charging mode: $\mathrm{SC}$ voltage $\left(U_{S c}\right)$ and $\mathrm{SC}$ current $\left(I_{S C}\right)$.

\section{B. Experimental Results}

At the very beginning of the SC charging process the $\mathrm{SC}$ current $I_{S C}$ can reach high values. To overcome this issue, the SC stack was charged up to $12.5 \mathrm{~V}$.

Fig. 10 shows that during the charging process the SS DC bus voltage $U_{S S}$ is constant and the SC stack voltage $U_{S C}$ increases up to the nominal value $(28.8 \mathrm{~V})$. At the beginning of the charging process the SC stack current $I_{S C}$ (Fig. 10) is around $135 \mathrm{~A}$.

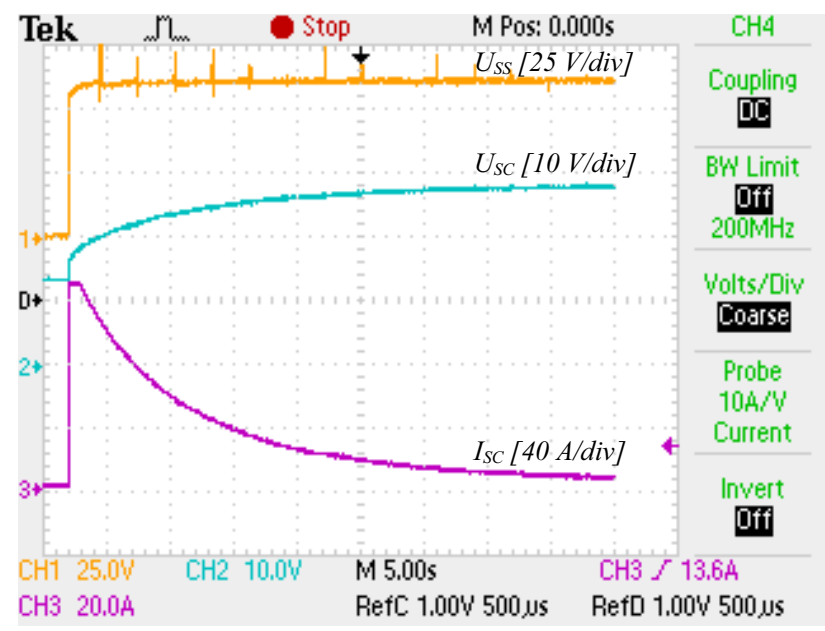

Fig. 10. Experimental waveforms of the charging process of the SC: SS DC bus voltage $\left(U_{S S}\right)$, SC stack voltage $\left(U_{S C}\right)$, and SC stack current $\left(I_{S C}\right)$.

Figs. 10 and 11 show that experimental waveforms of the proposed converter are in full agreement with the same waveforms that were made in simulation software. 


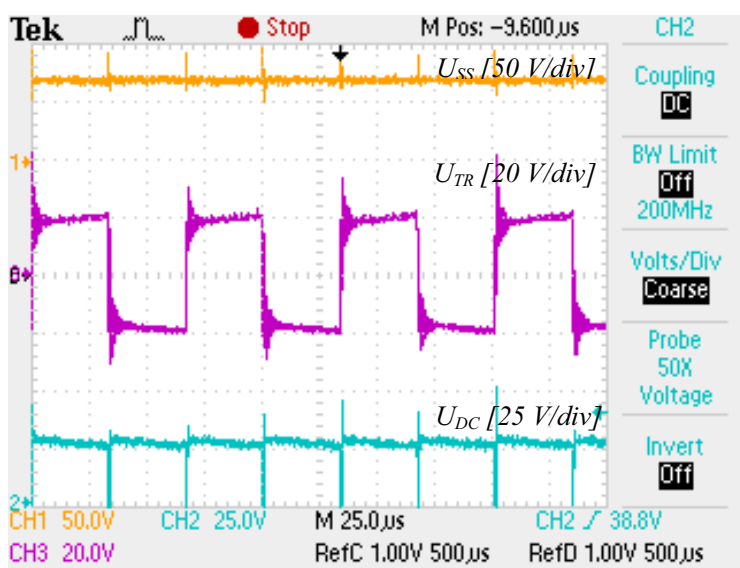

(a)

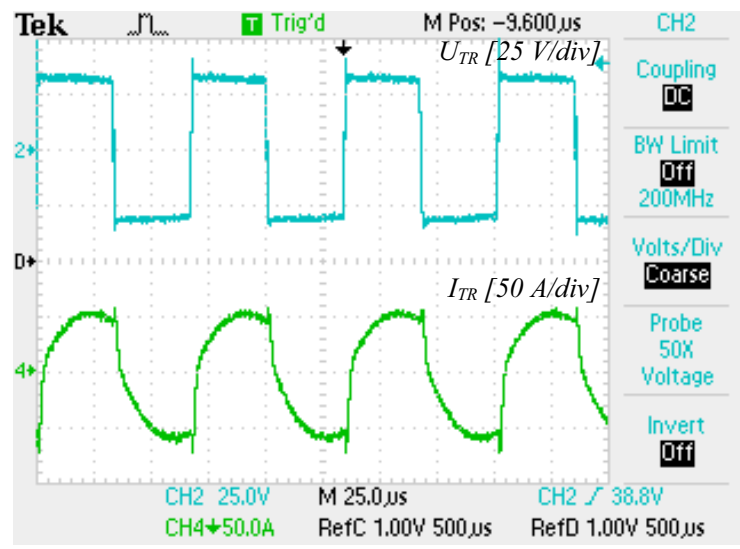

(b)

Fig. 11. Experimental waveforms during the SC charging mode: SS side voltage $\left(U_{S S}\right)$, transformer voltage $\left(U_{T R}\right)$, DC-link voltage $\left(U_{D C}\right)$ (a) transformer voltage $\left(U_{T R}\right)$, and transformer current $\left(I_{T R}\right)$.

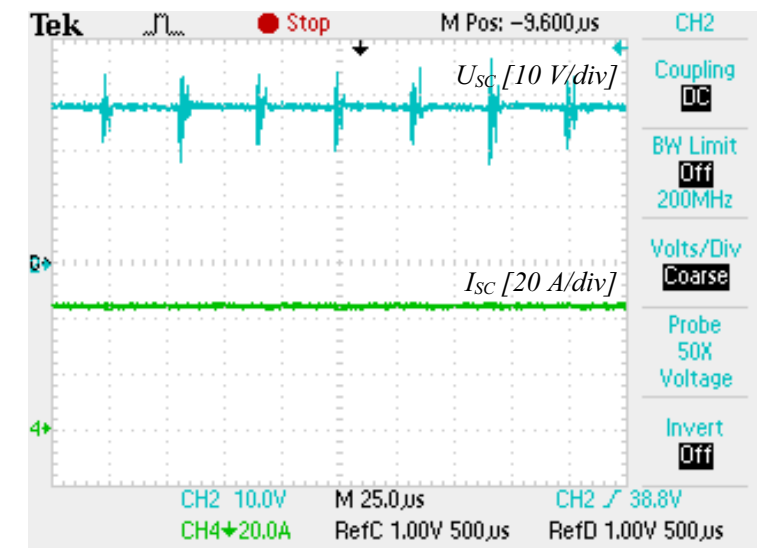

Fig. 12. Experimental waveforms during the SC charging mode: SC voltage $\left(U_{S C}\right)$ and $\mathrm{SC}$ current $\left(I_{S C}\right)$ during steady state.

\section{CONCLUSIONS}

This paper presents a qZSI-based bi-directional DC/DC converter for SC interfacing in high power applications. The main emphasis of this study was on the operation in the SC charging mode. Main operation principles as well as expressions to calculate currents and voltages of the qZS-network elements were presented.

The PSIM simulation results of the discussed converter were verified by a $500 \mathrm{~W}$ experimental setup. Results obtained in the experiments are in good agreement with the theory and simulations.

It was shown that during the charging mode of the SC the qZS network can work as a low-pass filter, which smoothens SC current without distortion of the SS side DC-link voltage and current.

\section{ACKNOWLEDGMENT}

This research work was supported by the Estonian Ministry of Education and Research (Project SF0140016s11), Estonian Science Foundation (Grant ETF8538) and European Social Fund (project „Doctoral School of Energy and Geotechnology II". This work has (partially) been supported by National Energy Research Programme of Republic of Latvia.

\section{REFERENCES}

[1] Fang Zheng Peng: Z-source inverter, IEEE Transactions on Industry Applications, vol.39, no.2, Mar/Apr 2003, pp. 504510

[2] Vinnikov, D.; Roasto, I.; Zakis, J.; Strzelecki, R.: New StepUp DC/DC Converter for Fuel Cell Powered Distributed Generation Systems: Some Design Guidelines", in journal "Electrical Review" ISSN 0033-2097, Vol. 86., Nr 8., 2010, pp. 245-252.

[3] Roasto, I.; Vinnikov, D.; Jalakas, T.; Zakis, J.; Ott, S.: Experimental study of shoot-through control methods for qZSI-based DC/DC converters, Proc. of SPEEDAM ' 10 Symposium, 14-16 June 2010, pp. 29-34.

[4] Vinnikov, D.; Roasto, I.; Zakis, J.: New bi-directional $D C / D C$ converter for supercapacitor interfacing in highpower applications. Proc. of 14th Power Electronics and Motion Control Conference EPE-PEMC 2010, 6-8 September 2010, pp. 38-43.

[5] Zakis, J.; Vinnikov, D.; Roasto, I.; Ribickis, L.: Quasi-ZSource Inverter Based Bi-Directional DC/DC Converter: Analysis of Experimental Results. In Proc. of CPE 2011 conference, 1-3 June 2011, pp. 394-399.

[6] Zakis, J.; Vinnikov D.; Roasto I.; Ribickis L.: Experimental Verification of Novel Bi-Directional qZSI Based DC/DC Converter for Short Term Energy Storage Systems. Proc. of ICREPQ 2011 Conference on Renewable Energies and Power Quality, 13-15 April 2011, pp. 1-6. 